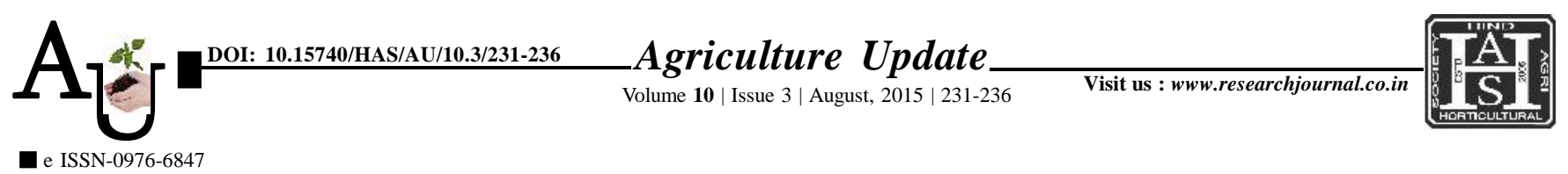

\title{
Research article: Farmers profile and their perception regarding environmental hazards caused through injudicious use of chemicals in paddy cultivation
}

\author{
I KESHA RAM, J.K. PATEL AND GORDHAN SINGH BHATI
}

Article Chronicle :

Received :

15.07.2015;

Revised :

17.07.2015;

Accepted :

12.08.2015

KEY WoRDS :

Profile of paddy

growers, Perception

Author for correspondence :

\section{KESHA RAM}

Department of Extension Education,

B.A. College of

Agriculture, Anand

Agricultural University,

ANAND (GUJARAT) INDIA

Email: keshavpancha199

@ gmail.com

See end of the article for

authors' affiliations
SUMMARY : This study was carried out in Anand district of Gujarat state with specific objectives to study the profile of paddy growers and their perception regarding environmental hazards. The study revealed that more than half $(56.00 \%)$ of the paddy growers belonged to middle age group, more than two-fifth $(42.00 \%)$ of the paddy growers had primary level of education, nearly half of the respondents (46.66\%) had low (upto 10 years) experience, majority (63.33\%) of the paddy growers had membership in one-organization. Nearly two-fifth (40.66\%) of the paddy growers had medium size of land holding, less than one-third of the paddy growers (30.00\%) had annual income ranging from Rs. 2,00,001 to $3,00,000$ lakh, more than two-fifth $(41.33 \%)$ of the paddy growers had medium level of extension contact, slightly more than half (52.67\%) of paddy growers had medium level of mass media exposure, slightly more than half $(52.00 \%)$ of the paddy growers had medium degree of economic motivation, majority $(70.67 \%)$ of the paddy growers had medium risk orientation, more than three- fifth $(62.00 \%)$ of paddy growers had medium level of scientific orientation, more than half $(53.33 \%)$ of the paddy growers had medium level of knowledge pertaining to eco-friendly technology, great majority (70.00\%) of the paddy growers had neutral attitude towards global warming, majority $(53.33 \%)$ of the respondents had medium level of adoption of eco-friendly technology and great majority (73.34\%) of the paddy growers had medium level of perception pertaining to environmental hazards caused through injudicious use of chemicals in paddy cultivation among the different independent variables, viz., education, scientific orientation, knowledge, attitude and adoption had positive and highly significant correlation with perception level of paddy growers in relation to environmental hazards caused through paddy cultivation. whereas, farming experience, social participation, mass media exposure, economic motivation and risk orientation of the paddy growers exerted positive and non-significant influence.

How to cite this article : Ram, Kesha, Patel, J.K. and Bhati, Gordhan Singh (2015). Farmers profile and their perception regarding environmental hazards caused through injudicious use of chemicals in paddy cultivation. Agric. Update, 10(3): 231-236. 